\title{
RECENZJE KSIĄŻEK W CZASOPISMACH NAUK SPOŁECZNYCH ZNACZENIE I ZAGROŻENIA
}

\section{WPROWADZENIE}

Poniższe rozważania dotyczą roli recenzji publikacji naukowych zamieszczanych w wyodrębnionych działach czasopism naukowych. Recenzje pełnia ważną rolę w upowszechnianiu, cyrkulacji wiedzy, idei i koncepcji naukowych w poszczególnych środowiskach naukowych, jak również służą budowaniu autorytetu zarówno autorów recenzowanych książek, jak i recenzentów. Zagadnienia związane $\mathrm{z}$ recenzowaniem tekstów naukowych są przedmiotem rozważań związanych i z warsztatem, i z wymaganiami, w tym także odnoszącymi się do zagadnień etycznych recenzentów artykułów publikowanych w czasopismach naukowych. Dyskusje i ustalenia publikowane sa przez Council of Science Editors ${ }^{1}$. Z zainteresowaniem spotkały się również recenzje prac na tzw. stopień: prac doktorskich i habilitacyjnych, których analiza wykorzystujaca metody analizy dyskursu, zdaniem Grażyny Woronieckiej, pozwala na ukazanie w szerszych kontekstach teoretycznych i historyczno-politycznych przeobrażeń tej praktyki społecznej. Pozwala na lokalizowanie mód i trendów naukowych, stopnia konformizmu politycznego, różnic zdań w kwestii standardów uprawiania dyscypliny między poszczególnymi ośrodkami naukowymi. Analiza umożliwia także identyfikację punktów spornych w danej dyscyplinie i określenia stopnia wyodrębnienia się krytyki naukowej od rozumowań potocznych ${ }^{2}$.

Zaprezentowaną w artykule analizę oparłem na recenzjach zamieszczonych w roku 2015 w czterech czasopismach: dwóch socjologicznych - „Kultura i Społeczeństwo” oraz „Przegląd Socjologiczny”, i dwóch z zarządzania „Organizacja i Kierowanie” oraz „Zarządzanie Zasobami Ludzkimi”. Ranga czasopism jest podobna, o czym świadczy zbliżona liczba punktów przyznanych przez Ministerstwo Nauki i Szkolnictwa Wyższego, i należą one do czołowych w swoich dyscyplinach. W niniejszej analizie postawiłem następujące pytania: czym autor recenzji uzasadniał powód zajęcia się recenzowaną książką i decyzją o opublikowaniu swojego tekstu? W jaki sposób ta inspiracja do przedstawienia recenzowanej książki wpływa na jej treść i sposób prezentacji?

\footnotetext{
${ }^{1}$ Por. Reviewer Roles and Responsibilities.

${ }^{2}$ Por. Woroniecka (2015).
} 
W szczególności, czy konfrontuje tezy autora książki z książkami innych autorów i ich ustaleniami? Czy wyraża oceny? Jak je uzasadnia? Czy uwzględnia perspektywą czytelnika, adresata recenzowanej książki?

Odpowiedzi na te pytania nie maja służyć ocenie analizowanych recenzji, maja pomóc w dostrzeżeniu zjawisk i procesów dokonujących się niejako na obrzeżach zmian zachodzących we współczesnej nauce, szczególnie jej wymiarze instytucjonalnym. Spośród tych zmian zwróciłbym uwagę na zmiany dotyczące wzoru uczonego, badacza, norm i sposobów oceny jego dorobku i pozycji w środowisku. Dokonujące się od kilku lat zmiany charakteryzuja się olbrzymim zwiększeniem liczby badaczy i naukowców, zwiększeniem liczby publikacji, wprowadzeniem punktacji poszczególnych rodzajów publikacji i czasopism, uwzględnieniem wskaźników cytowań. Wpływają one na zmiany zasad oceny pozycji naukowców w ich środowiskach, na ich strategie działania, wreszcie na system wartości i norm w środowiskach naukowych. Druga sfera dotyczy wpływu rynku, ekonomizacji działania, która również dosięgła świat nauki. Urynkowienie dotyczy także wydawców książek naukowych, przy czym najważniejsze sa nie tyle warunki, w jakich działaja wydawnictwa, ile potraktowanie książki naukowej jako produktu i podejmowanie związanych z nią działań marketingowych, co wyraża się nie tylko w znacznie lepszej niż przed laty jakości papieru czy okładce, ale również w charakterystyce autora i książki zamieszczonej na tylnej okładce. Można przypuszczać, że zmiany te wywierają wpływ na zachowania naukowców, w tym również na pisane przez nich recenzje książek. Zmiany te nieco w sarkastycznym tonie scharakteryzował przed laty Stanisław Andreski: „Przychodzi mi do głowy nieco zabawny przykład: czytałem niedawno recenzję książki opisującej wpływ, jaki w małych społecznościach (głównie indyjskich) mają lokalni politycy. W opinii recenzenta praca ta była znacznie lepsza niż dzieła Machiavellego. Zapomniał dodać, że jej autor był równie lepszym podróżnikiem niż Vasco da Gama, dojechał bowiem do Indii i z powrotem znacznie szybciej”3.

\section{ANALIZA RECENZJI}

Porównanie liczby recenzji książek, które opublikowano w analizowanych czasopismach w numerach wydanych w 2015 r., pokazuje istotne różnice. W „Organizacji i Kierowaniu” zamieszczono tylko jedną recenzję oraz krótkie informacje o książkach pochodzace z fragmentów recenzji wydawniczych w dziale: Oficyna SGH Poleca. W „Zarządzaniu Zasobami Ludzkimi” w tymże roku 2015 zamieszczono 7 recenzji, a w „Przeglądzie Socjologicznym” - 8 . Najwięcej recenzji zamieszczono w „Kulturze i Społeczeństwie” - 13, a ponadto w dziale: Noty bibliograficzne, zawierającym również omówienia książek, tyle że podpisanych inicjałami autorów, opublikowano 17 not. Dodatkowo - na co warto zwrócić uwage - w „Kulturze i Społeczeństwie” opublikowano jedna

${ }^{3}$ Andreski (2002): 211. 
odpowiedź autorki książki na recenzję. Recenzje zamieszczone w tym czasopiśmie mają swoje własne tytuły nawiąujace nie tylko do problematyki recenzowanej książki, ale i wyrażające specyfikę uchwycona przez recenzenta. Wszystko to sprawia, że redakcja tego właśnie czasopisma zdaje się przykładać największą wagę do przeglądu i omówień piśmiennictwa.

Prezentację efektów przeprowadzonej analizy przedstawię przez charakterystykę trzech typów recenzji. Punktem wyjścia była analiza uzasadnień wyboru recenzowanej książki.

Typ pierwszy, który określiłbym jako recenzja książki wybitnego a utora, charakteryzuje się podkreślaniem osiagnięć, kompetencji, dorobku i pozycji środowiskowej jej autora lub autorów. Dobrą ilustrację stanowi charakterystyka autora książki recenzowanej przez Marię Romanowską : „Książka jest podsumowaniem kilkudziesięciu lat doświadczeń naukowych, dydaktycznych i praktycznych Profesora Lichtarskiego, próbą podzielenia się z Czytelnikami najważniejszymi spostrzeżeniami i przemyśleniami” ${ }^{5}$. Taki punkt wyjścia powoduje, że treść książki jest przedstawiana przez wskazanie działań podejmowanych przez jej autora, który: „dokonał zwięzłego opisu genezy i rozwoju dyscypliny, zdefiniował pojęcie zarządzania i jego granice oraz skupił się na omówieniu współczesnych koncepcji zarządzania”. W przedstawieniu treści książki brak odniesienia do stanu wiedzy dotyczącej jej problematyki czy występujących w nich kontrowersji. Mimo wskazania na praktyczne implikacje badań stanowiących empiryczną podstawę formułowanych wniosków oraz praktyczny dorobek autora, recenzentka nie konfrontuje wyników badań z problemami, jakie napotyka praktyka zarządzania. Czytelnik recenzji musi zawierzyć autorytetowi autora i recenzenta w kwestii wartości tej „niezwykle inspirującej książki”. Wartość dla praktyki zarządzania, wątek wielokrotnie przewijajacy się w recenzjach książek z tej dyscypliny, w tym przypadku nie leży w „aktywności w zakresie badań i współpracy, ale w zmianie podejścia do budowania relacji nauki i praktyki zarządzania”. Dlatego płynace z niej inspiracje - zdaniem recenzentki - kierowane są do naukowców, przedstawicieli tej dyscypliny. „Trzeba mieć nadzieję, że swoją książką Profesor zmobilizuje nasze środowisko do podjęcia dyskusji na temat: jak badać rzeczywistość i tworzyć nowoczesne koncepcje zarządzania i jak wspierać menedżerów w ich wdrażaniu"6.

Podobna, mieszczacca się w tym typie recenzji jest tekst Wojciecha Sadłonia poświęcony książce Janusza Mariańskiego ${ }^{7}$ : „Janusz Mariański jest z jednym z najczęściej publikujących w ostatnich latach polskich socjologów, jego prace mieszczą się zasadniczo w dwóch związanych ze sobą obszarach socjologii religii i socjologii moralności. Bogaty dorobek autora [...] obejmuje przede wszystkim prace o charakterze syntetyzującym i przeglądowym, ale oparte zasadniczo o wyniki badań empirycznych"8. Treść książki, będącej podręcznikiem, przedstawiono bez odniesienia się do innych tego typu publika-

\footnotetext{
${ }^{4}$ Por. Romanowska (2015).

${ }^{5}$ Romanowska (2015): 205.

${ }_{6}$ Romanowska (2015): 208.

7 Por. Sadłoń (2015).

8 Sadłoń (2015): 181.
} 
cji i referowano przez wskazanie na działania podejmowane przez jej autora, czasami opatrzone wartościującymi określeniami: „Mariański skrupulatnie zarysowuje ramy socjologii moralności jako socjologicznej subdyscypliny [...]". Sadłoń używa form osobowych „autor przedstawia”, „prezentuje”, „omawia”, w odniesieniu nie do podstawowych problemów socjologii moralności, a do referowania zawartych w książce zagadnień. Zasadniczo recenzent nie polemizuje z autorem książki ani nie wysuwa wątpliwości, a jeśli, to z zastrzeżeniem, jak w przypadku braku diagnozy przemian moralności w kontekście procesów globalizacji: „Ten niedosyt łagodzi nieco prezentacja w dalszej części modelów przemian wartości i norm moralnych w nowoczesnych społeczeństwach", w ramach których znalazły swoje miejsce takie zjawiska, jak: sekularyzacja, indywidualizacja, pluralizacja oraz reorientacja wartości”’.

Drugi zaproponowany typ recenzji określiłbym jako recenzja książki poruszającej interesujący problem. Stawia ona nieco inne i wyższe wymagania przed recenzentem, gdyż ten „interesujacy problem” nie jest sam w sobie oczywisty i recenzent stara się, przedstawiając odpowiednie argumenty, przekonać do niego czytelnika. Tak czyni Elżbieta Tarkowska w recenzji książki poświęconej socjologii muzyki ${ }^{10}$ : „W znanej serii »Wykłady z socjologii« [...] ukazała się ciekawa i wartościowa książka. Jest to praca pionierska na polskim gruncie, pomyślnie przerywająca dotychczasowa praktykę nieobecności w socjologii problematyki związanej z muzyka" ${ }^{11}$. Tezę tę uzasadnia, wskazując zarówno na brak nowych pozycji z literatury poświęconej socjologii muzyki, jak i na całościowe ujęcie socjologicznej problematyki muzyki przedstawionej przez autorkę książki. Omawiając treść książki, konfrontuje założenia przyjmowane przez Barbarę Jabłońską z jednej strony z różnymi aspektami funkcjonowania muzyki w społeczeństwie, $\mathrm{z}$ drugiej - $\mathrm{z}$ różnymi koncepcjami teoretycznymi dotyczącymi współczesnej kultury. Tarkowska ostrożnie operuje określeniami odnoszącymi się do autorki książki, skupiając się na ocenie zaprezentowanej przez nią socjologicznej refleksji nad muzyką. Takie podejście zawiera w sobie również uwagi i pytania, w szczególności dotyczące nieuwzględnienia w pełni współczesnej refleksji nad kulturą współczesna, odwołania się do koncepcji łączącej wymiary audialny i wizualny, opozycji stanowiącej punkt wyjścia prezentacji koncepcji socjologii muzyki przez Jabłońska. Takie skupienie się w recenzji na „interesujacym problemie” wyraża się nie tylko w prezentacji jej zawartości, ale również w uzasadnieniu oceny jej wartości. „Książka stanowi wkład do dyskusji”, „,zainicjowanie debaty naukowej na temat stanu i perspektyw socjologii muzyki”, „inicjowanie badań”. „Książka jest ważnym etapem w konstruowaniu tożsamości i odrębności tej subdyscypliny socjologicznej" 12 .

Drugim przykładem tego typu recenzji jest recenzja książki poświęconej społeczeństwu obywatelskiemu ${ }^{13}$. „Teza o słabym społeczeństwie obywa-

\footnotetext{
9 Sadłoń (2015): 183.

10 Por. Tarkowska (2015).

11 Tarkowska (2015): 200.

12 Tarkowska (2015): 201.

13 Por. Rakusa-Suszczewski (2017).
} 
telskim, które musiało być budowane od podstaw, jest nieuprawomocniona i niesprawiedliwa, a wynika głównie z wadliwego ujęcia tej problematyki. Do rewizji dominującej koncepcji skłania istnienie licznych i nieudokumentowanych przejawów aktywności obywatelskiej, stowarzyszeń i kooperatyw (tzw. starego trzeciego sektora), które w enklawach wolności funkcjonowały poza bezpośrednią kuratelą totalitarnych państw"14. Recenzent wskazuje zatem na koncepcje teoretyczne, na gruncie których formułowane są tezy przez autorów omawianej książki zakwestionowane. W konsekwencji prowadzi to nie tylko do wskazania na pozycje literaturowe odnoszące się do badanej przez autorów książki problematyki, ale - co obecne jest w dalszej części recenzji - do odwołania się do empirii, przeobrażeń współczesnych społeczeństw. Skupienie się przez recenzenta na „interesujacym problemie” znajduje odzwierciedlenie w prezentacji treści książki, użyciu czasowników wskazujących na zmaganie się autorów książki z problemem, polemizowaniu autorów książki z obecnymi w nauce ustaleniami, uzasadnianiu stawianych tez: „Autorki i autorzy proponuja porzucić sztywne dychotomie, które wyłoniły się w dobie postsocjalistycznej transformacji, na rzecz bardziej uważnych analiz macierzystego charakteru społeczeństwa obywatelskiego"15. Przedstawienie argumentacji autorów książki, że „bezkrytyczne transplantowanie pojęć i ideałów prowadzi do nazbyt prostych i uogólnionych wyobrażeń, a co gorsza, do konceptualnego, a także praktycznego wykluczania oraz dyskredytowania istotnych obszarów życia społecznego i przejawów inicjatywy obywatelskiej”, pozwala recenzentowi na włączenie się to dyskusji i przedstawienie uwag, zastrzeżeń i pytań.

Taki sposób podejścia do charakterystyki treści książki i dokonań jej autorów pozwala czytelnikowi recenzji na wyrobienie sobie opinii o ocenie książki i dokonaniach autorów przez jej recenzenta, bez używania przez niego wartościujących charakterystyk autorów. Użyte sformułowania i wyrażane pytania i wątpliwości uzupełniają wcześniejszy wywód i służą budowaniu wizerunku recenzenta jako osoby kompetentnej, pomagającej czytelnikowi krytycznie ocenić recenzowaną książkę. W żadnym stopniu nie podważają sformułowanej na początku recenzji pozytywnej jej charakterystyki, jako „kolekcji interesujących tekstów z mocną tezą metodologiczną i równie silnym, demokratycznym przesłaniem [...]".

Oprócz dwóch przykładów takich czystych typów recenzji spotykamy również typy mieszane. W przypadku recenzji książki w czasopiśmie z zarządzania „interesujacca problematyka” została uzasadniona przez wskazanie, że „[p]raca stanowi nowoczesne ujęcie zagadnień związanych z niezwykle istotna i aktualna problematyką elastyczności w obszarze ZKL"16. Prezentacja treści książki przedstawiona została za pomoca czasowników wskazujących na jej zawartość, a nie na pokazanie działań badawczych czy intelektualnych zmagania się z ,interesującym problemem”: „omówiono szereg zagadnień związanych z elastycznością z perspektywy dwóch grup interesariuszy, właścicieli

\footnotetext{
14 Rakusa-Suszczewski (2017): 142.

15 Rakusa-Suszczewski (2017): 144.

16 Lewicka (2018): 107.
} 
i menedżerów”, „zaprezentowano ciekawe rozważania dotyczace firm rodzinnych”, „omówiono różne perspektywy i metody pomiaru kapitału ludzkiego”, „zaprezentowano wyniki stosownych badań empirycznych przeprowadzonych przez zespół autorski”. Prezentacji treści książki nie towarzyszą jednak żadne argumenty uzasadniające użycie wartościujących określeń dotyczących recenzowanej książki: „ciekawe przemyślenia na temat komponentów elastyczności ZKL, zilustrowanych wynikami badań empirycznych”, „wartościową inicjatywą jest wskazanie zakresu możliwych działań, które mogą podejmować różne grupy interesariuszy w organizacji”, ,interesującym wzbogaceniem prezentowanych zagadnień o dużej przydatności dla praktyki gospodarczej sa także zamieszczone przykłady i wyniki badań empirycznych". Nagromadzenie silnie wartościujących, pozytywnych określeń recenzowanej książki, bez odwołania się do przykładów czy omówienia badań będących jej podstawa, powoduje, że prezentacja przez recenzentkę interesującego problemu jest ściśle związana z oceną zespołu autorskiego określanego jako „znanego z wysokiego poziomu opracowań naukowych”, autorów pracy, która „stanowi nowoczesne ujęcie zagadnień związanych z niezwykle istotną i aktualną problematyką elastyczności w obszarze ZKL”. Książka w podsumowaniu została określona jako „opracowanie kompleksowe, o istotnych walorach poznawczych i dydaktycznych, oraz inspirujące źródło pomysłów dla szerokiego grona odbiorców". Osobiste uwagi i pytania recenzentki pod adresem książki mogłyby wzmacniać tę ocenę, jednakże ich brak powoduje, że czytelnikowi pozostaje zawierzenie autorytetowi autorów książki i recenzenta.

Drugim przykładem typu mieszanego jest recenzja książki Marty Bucholc poświęconej socjologii Norberta Eliasa ${ }^{17}$. Recenzent Janusz Mucha rozpoczyna od ukłonu w kierunku autorki, wskazując na jej osiągnięcia $\mathrm{w}$ analizie koncepcji niemieckiego socjologa, i przywołania innych recenzji książki Bucholc. „Znaczenie książki i całego eliasologicznego dorobku Marty Bucholc widzę nie tylko w przybliżeniu polskiemu czytelnikowi koncepcji autora wciąż pozostającego na "marginesach" [...]"18. Doceniając sposób podejścia autorki do eliasowskiej socjologii: „Wysoko cenię sobie to, co autorka pisze o [...]”, „Bardzo mi się podoba ambicja, aby spróbować teoretyzowania potoczności”, w prezentacji treści książki występuje nie tylko jako uważny czytelnik, ale osoba konfrontująca własne i innych spojrzenie na koncepcję Eliasa z propozycją przedstawiona przez Bucholc. Wskazuje na dwie możliwe interpretacje twórczości Eliasa, zauważając niedostatek rozważań metodologicznych: „W recenzowanej książce brakuje mi świadomej, wyrażonej explicite metodologii pracy nad tekstami Eliasa. Jej ślady jednak widzę na przykład wtedy, gdy mowa o rozmaitych "socjogenezach""19. Recenzja napisana jest w pierwszej osobie, jest refleksją Muchy czytającego książkę Bucholc: „Nie wiem, dlaczego tak się dzieje [...]. Nie będę tych wątków rozwijał szczegółowo”. „Wspomnę tu jeszcze, że jej dość ograniczony krytycyzm wo-

\footnotetext{
17 Por. Mucha (2015)

18 Mucha (2015): 198.

19 Mucha (2015): 198.
} 
bec koncepcji Eliasa (wrócę do tego) wynika, jak czytamy na przykład na s. 40 , z tego, iż [...]" 20 .

Tekst recenzji zawiera liczne pytania i wątpliwości uwzględniające odwołania się nie tylko do tekstu książki, lecz także do interpretacji innych autorów zajmujących się socjologią Eliasa; przykładowo: „Chciałbym jednak wiedzieć co autorka sądzi o sposobie użycia terminu "cywilizacja» przez Eliasa w kontekście trwających od dawna sporów, jak ten sposób ma się do dzisiejszych debat. Z książki nie dowiaduję się tego”. Rozważania Muchy dotyczą relacji między teoriami socjologiczną a społeczna. Formułowane przez niego uwagi dotyczą definiowania pojęć, odniesienia interpretacji autorki książki do innych interpretacji, odniesienia się przez nią do żywych w naukach społecznych sporów. Co ważne, w recenzji brak podsumowania, polecenia książki czytelnikom czy używania jakichkolwiek określeń do niej się odnoszących. Pytania i uwagi sformułowane przez Muchę z jednej strony mają charakter osobisty, wynikaja z jego lektury i uwzględniająjego wiedzę socjologiczna. Z drugiej - są pomocne czytelnikowi, nie tylko książki Bucholc, ale również innych książek naukowych, gdyż pokazuja, że konieczne jest zwrócenie uwagi na metodologię, na osadzenie swoich badań i interpretacji w ustaleniach innych badaczy.

Trzeci typ recenzji spotykamy w czasopiśmie „Zarządzanie Zasobami Ludzkimi” (ZZL); wynika on z profilu pisma adresowanego zarówno do naukowców zajmujących się problematyką zasobów ludzkich, jak i praktyków (choć - o czym należy pamiętać - w okresie transformacji gospodarczej i społecznej nastapiły procesy profesjonalizacji zarządzania zasobami ludzkimi i specjaliści z tej branży posiadają własne stowarzyszenie: Polskie Stowarzyszenie Zarządzania Kadrami i czasopismo: „Personel i Zarządzanie”). Autorami nie tylko artykułów, ale i recenzji książek i komunikatów zamieszczonych w ZZL są pracownicy naukowi, niemniej z racji misji pisma można wyróżnić typ recenzji, który określiłbym jako recenzja książki adresowanej do praktyków. Nawiasem mówiąc, to wskazanie na czytelników książki jest obecne prawie w każdej recenzji publikowanej w czasopismach z dziedziny zarządzania, podkreślenie, że przydatna jest zarówno dla teoretyków, jak i praktyków, studentów kierunku zarządzanie, jak i studiów podyplomowych. Wynika to zarówno z podkreślania praktycznego wymiaru nauk o organizacji i zarządzaniu, jak i wpływu podejścia marketingowego do promocji książek, co dostrzegalne jest w formie recenzji, szczególnie zaś widoczne jest w dziale Oficyna Wydawnicza SGH Poleca zamieszczonym w „Organizacji i Kierowaniu” (2015, nr 1), w którym zamieszcza się fragmenty recenzji wydawniczych umieszczone na tylnej okładce książek. Jako przykład ilustrujący to podejście może służyć następujący fragment recenzji. „Rozważania w niej podjęte oraz wnioski wynikajace z przedstawionych badań empirycznych mogą być cennym źródłem informacji, pomocnym przy opracowaniu strategii rozwoju przedsiębiorstw oraz przy formułowaniu i wdrażaniu kierunków polityki gospodarczej, a w szczególności polityki innowacyjnej. Przedmiot i zakres monografii powo-

${ }^{20}$ Mucha (2015): 198. 
duje, iż może ona stanowić cenną pomoc zarówno dla teoretyków i praktyków zarządzania, jak i studentów kierunków ekonomicznych” (s. 166).

Przykładem tego typu (trzeciego) recenzji jest recenzja książki Maria Hergera Gamification in Human Resources autorstwa Jacka Woźniaka ${ }^{21}$. Autor recenzji jest redaktorem tomu czasopisma ZZL poświęconego problematyce wykorzystywania gier w szkoleniu menedżerów, w którym zamieszczona jest ta recenzja. We wprowadzeniu do tomu i oddzielnym artykule szczegółowo omawia problematykę grywalizacji, odwołując się do światowej literatury z tego zakresu, co wyjaśnia i uzasadnia nieobecność rozważań teoretycznych w recenzji. Samą zaś recenzję rozpoczyna od charakterystyki autora pracy, przedstawiając jego wykształcenie i działalność, podkreślając, że jest to działalność badawcza i konsultingowa. Wskazuje na cel, jaki przyświecał autorowi w jej pisaniu: ,[...] zainteresowanie i zachęcenie do wprowadzenia grywalizacji koordynowanej przez zarząd i działy HR, jako działania zwiększającego skuteczność organizacji”22. Podkreśla walory książki: „żywo napisana, bogato ilustrowana”. Podkreśla, że nie jest to książka naukowa. Pokazuje możliwości, jakie dla działów HR stwarza grywalizacja. Omawiając zawartość książki, wskazuje na zebrane w niej przykłady wykorzystania metody oraz korzyści, jakie mogą osiagać wykorzystujace je działy HR. Przywołuje badania Gallupa wskazujące na niski poziom zaangażowania pracowników w organizacjach, co ma uzasadniać i zachęcać do stosowania omawianych metod. Wskazuje również na aspekty właściwe podejściu naukowemu, wskazując na związek rywalizacji z motywacją z jednej strony i zadaniami stojącymi przed działami HR z drugiej. Uzasadnia znaczenie grywalizacji przez odwołanie się do postaw i oczekiwań wobec pracy pokolenia milenialsów. Poradnikowy i popularnonaukowy charakter książki podkreśla przez zwrócenie uwagi na prowadzenie wykładu „według kolejnych obszarów HR, w których grywalizacje sa stosowane"23, i podanie przykładów możliwości wykorzystania gier. Zamieszczenie recenzji książki o charakterze popularnopodręcznikowym uzasadnia naukową podstawą proponowanych przez Hergera rozwiązań: „Choć w książce nie pojawiają się odniesienia do literatury naukowej, to takie wykorzystanie ma dobre uzasadnienia naukowe, w badaniach dotyczących zarówno realistycznego obrazu pracy, jak i kształtowania wizerunku firmy jako pracodawcy" ${ }^{24}$. Woźniak omawia książkę w kontekście problemów, jakie napotyka zarządzanie ludźmi we współczesnych organizacjach. Odwołuje się do tekstu książki, wprowadzając do recenzji jej fragmenty. Połączenie charakterystyki autora książki nie przez użycie wartościujących określeń dotyczących jego osoby, ale wskazanie na to, co robi, i jak to, co robi, znajduje odzwierciedlenie w praktyce zarządzania, przedstawia wzór konsultanta jako atrakcyjny dla kariery nie tylko praktyków zarządzania, ale i naukowców łączących wiedzę teoretyczną z badaniami i doradztwem.

\footnotetext{
21 Por. Woźniak (2015).

22 Woźniak (2015): 157.

23 Woźniak (2015): 158.

24 Woźniak (2015): 159.
} 
Powyższe podejście do recenzowania pozwala na budowanie wizerun$\mathrm{ku}$ autora recenzji jako specjalisty w tej problematyce. Służy temu nie tylko swobodne poruszanie się w problematyce zarządzania zasobami ludzkimi, ale i znajomość problemów, jakie napotykaja praktycy. Pozwala na stawianie pytań i wyrażanie wątpliwości: „Mniej oczywiste są przykłady zastosowań grywalizacji w obszarach zarządzania talentami, kariera czy oceną pracy" ${ }^{25}$. Nie ogranicza się do wskazania, że książka adresowana jest do praktyków zzl, ale tezę tę uzasadnia, odwołując się do zawartości i formy książki: „Bardzo użyteczne praktycznie są krótkie podrozdziały, przynoszące dane ilustrujące korzyści wynikające ze stosowania grywalizacji z obszaru wskaźników zarządzania praca, rekrutacji czy reputacji jak również kosztów wprowadzania projektów, [...] dobrze się stało, że Herger zebrał szereg przykładów stosowania rozwiąań grywalizacyjnych w HR, a jasność wykładu i prostota przekazu pozwalaja zrozumieć, że grywalizacja nie jest hipotetyczną możliwościa, a faktem w tym obszarze zarządzania. Dobrze się również stało, że słabości teoretyczne, jakimi obciążona jest zawarta w książce prezentacja grywalizacji, sa oczywiste i nie utrudniają czytania"26.

Ten typ recenzji reprezentuje również recenzja książki Elżbiety Kowalczyk Człowiek - organizacja-kariera. Siła psychologii stosowanej autorstwa Adeli Barabasz, która na początku uzasadnia wybór książki, wskazując jej adresatów: „Recenzowana książka jest propozycją skierowaną do szerokiego spektrum odbiorców. Jej tytuł zaciekawia, wzbudza chęć zapoznania się z zawartościa, daje nadzieje na poszerzenie wiedzy psychologicznej”"27. W dalszej części recenzji wymienia konkretne kategorie czytelników: „studentów, słuchaczy studiów podyplomowych, szczególnie menedżersko-ekonomicznych, ale także tzw. przeciętnego czytelnika, jednym słowem wszystkich, którzy sa zainteresowani wzbogacaniem wiedzy psychologicznej o sobie i otaczającym nas świecie"28. Uwagi te organizują tekst, w którym recenzentka skupia się na podkreśleniu umiejętności przedstawiania wiedzy psychologicznej autorki książki praktykom zarządzania oraz jej kompetencji merytorycznych: „[A]utorka z powodzeniem łączy podejście typowe dla psychologii jednostki z psychologia organizacji”" . „Proponuje z jednej strony tematy klasyczne z obszaru psychologii zarządzania, z drugiej wprowadza zagadnienia stosunkowo nowe" ${ }^{30}$, co ilustruje przykładami z książki. Podkreśla innowacyjność ujęcia tej problematyki przez Kowalczyk: „Treści te zazwyczaj podejmowane w pracach z pogranicza psychologii i zarządzania, autorka uzupełniła, z dużym wyczuciem i wnikliwościa, znacznie rzadziej podejmowanymi zagadnieniami, takimi jak [...]”; „Powiązanie problematyki właściwej dla psychologii ogólnej, psychologii społecznej z zagadnieniami ważnymi z perspektywy za-

\footnotetext{
25 Woźniak (2015): 159.

26 Woźniak (2015): 161.

27 Barabasz (2015): 165.

28 Barabasz (2015): 168.

29 Barabasz (2015): 166.

30 Barabasz (2015): 166.
} 
rządzania jest zadaniem trudnym. Elżbiecie Kowalczyk to ambitne przedsięwzięcie powiodło się" 31 .

Omówienie książki podporządkowane jest potencjalnemu czytelnikowi. Recenzentka podkreśla takie jej walory, które dotyczą „wewnętrznej spójności” i „wyważonego układ treści”, co ułatwia lekturę książki i sprawia, że „czytelnik z łatwością podąża za tokiem wywodu autorki, mogąc jednocześnie prowadzić wewnętrzny, osobisty dialog z autorka, jej spostrzeżeniami, konkluzjami, czy też pytaniami, jakie pojawiają się w treści poszczególnych rozdziałów" ${ }^{2}$. Jednakże - podobnie jak w przypadku innej analizowanej recenzji recenzentka $\mathrm{w}$ taki dialog $\mathrm{z}$ autorka nie wchodzi. Kolejnym, ważnym dla czytelnika książki aspektem, szczególnie w przypadku książek adresowanych do praktyków, są przykłady, co recenzentka podkreśla jako jej walor: „[...] podejmowane w poszczególnych rozdziałach zagadnienia teoretyczne ilustrowane są przykładami zaczerpniętymi z obserwacji codziennego funkcjonowania ludzi, grup i organizacji czyni książkę ciekawą dla każdego czytelnika, który chciałby przyjrzeć się swojej sytuacji zawodowej z perspektywy psychologicznej" ${ }^{33}$. Istotnym walorem książki uchwyconym przez Barabasz jest również język, komunikatywność, odwołanie się do tematów nawiązujących do sytuacji życiowych i zawodowych czytelników, co sprawia, że jej autorka przybliża czytelnikowi wiedzę psychologiczna.

Opisana powyżej strategia recenzyjna służy zarówno czytelnikowi, którego Barabasz stara się zachęcić do lektury książki, służy autorce książki dzięki podkreślaniu walorów książki będącej owocem jej wiedzy, pasji i kompetencji, służy także samej recenzentce, która w ten sposób realizuje rolę naukowca przyczyniającego się do upowszechniania nauki, jaką sama uprawia.

Recenzowanie książek o charakterze poradnikowym przez naukowców w czasopiśmie naukowym, a takim jest ZZL, sprawia, że ich autorzy częściej niż w przypadku recenzji książek naukowych publikowanych w tym czasopiśsmie wyrażają uwagi i wątpliwości. Dotyczą one zarówno zagadnień teoretycznych i metodologicznych, a także kwestii etycznych. Janusz Strużyna, podkreślając dokonania autora na polu konsultingu i polecając książkę czytelnikom, którzy „z racji swojej misji zawodowej powinni wiedzieć więcej o motywacji, niż oferuje skrypt z HRM-u" ${ }^{34}$, poszukuje w niej odpowiedzi na postawione przez siebie pytania. Stawia nie tylko pytania, ale i wyraża uwagi dotyczące relacji między teoriami motywacji i pojęciem lojalności a rozwiązaniami organizacyjnymi proponowanymi przez autora książki.

Podobnie Waldemar Stelmach w recenzji książki Zarzadzanie twórcze, wyrażając pozytywną opinię o oryginalności i erudycji autorów, zwraca uwagę na braki teoretyczne dotyczące niezdefiniowania pojęcia „współczesnej organizacji” czy brak rozważań poświęconych zagadnieniu konkuren-

\footnotetext{
31 Barabasz (2015): 166-167.

32 Barabasz (2015): 165.

33 Barabasz (2015): 167.

34 Por. Strużyna (2015): 162.
} 
cyjności w rozdziale „Kapitał intelektualny w rozwoju konkurencyjności organizacji”. Zarzut ten opatruje następujacca uwagą: „a powinni, bo nie sprawiłoby to im kłopotu, jako że obaj są ekonomistami" ${ }^{35}$. Stelmach ogranicza się do omówienia zawartości rozdziałów, a na koniec daje dłuższy cytat z okładki książki zawierającej fragment recenzji wydawniczej, którą poprzedza stwierdzeniem: „[...] z którymi bez reszty się zgadzam i które bardzo trafnie oceniają książkę". Dwaj przywołani autorzy analizowanych recenzji, Stelmach i Strużyna, zdają się realizować taki wzór recenzenta - naukowca, którego rola jest stanie na straży obecności wiedzy naukowej w pracach popularnonaukowych, nie tylko uzupełnianie czytelnikom popularyzatorskiego wykładu, ale również zachęcenie ich do sięgnięcia po opracowania naukowe.

Z kolei Jerzy Wratny w recenzji książki poświęconej derekrutacji związanej z prawem pracy, napisanej przez pięcioro „młodych autorów związanych z wrocławską Kancelarią Olesiński \& Wspólnicy”36, doceniając ją jako „praktyczny poradnik adresowany do pracodawców”, podaje w wątpliwość „konsekwentnie realizowaną" ideę służenia interesom pracodawców, co odzwierciedla użyty w tytule neologizm „derekrutacja”. „Musi to budzić mieszane uczucia u recenzenta będącego przedstawicielem nauki prawa pracy, wychowanego na paradygmacie ochronnej funkcji tej gałęzi prawa" ${ }^{37}$. Pracownik w tej książce został bowiem przedstawiony jako sprytny przeciwnik, czyhający na potknięcia pracodawcy. W takiej sytuacji rolą autorów książki jest tropienie nadużyć rzekomych lub rzeczywistych popełnianych przez pracowników. Pozytywna ocena ksiażki jako poradnika wynika z rzetelnego przedstawienia a w niej stanu prawnego i nieobciążanie tekstu orzecznictwem oraz z tego, że nie tylko z dostarcza informacji opartych na obowiąującym prawie, lecz także $\mathrm{z}$,potrzeby umiejętnego sterowania emocjami [pracowników - P.G.], aby łagodzić napięcia wywołane wprowadzaniem w życie decyzji o zwolnieniu pracownika" ${ }^{38}$. Recenzent uwypukla rozbieżność między perspektywa praktyków zarządzania a naukowcem: podkreślając aspekty etyczne zarządzania, wskazuje na oczekiwania społeczne związane z etosem pracownika nauki, uwzględniania nie tylko szerszej perspektywy, lecz także interesu różnych grup społecznych i funkcji, jaką spełnia prawo.

Z przeprowadzonej analizy recenzji książek naukowych, które zostały zawarte w czterech wybranych czasopismach z nauk społecznych, wynika nie tylko obecność trzech wyróżnionych w artykule typów. Typy te w różnym stopniu reprezentowane są w poszczególnych tytułach. W „Kulturze i Społeczeństwie” najliczniej reprezentowany jest typ drugi, co powoduje, że recenzowane pozycje osadzone są nie tylko w kontekstach teoretycznych, ale również odniesione do książek innych autorów podejmujących tę problematykę, co pozwala auto-

\footnotetext{
${ }^{35}$ Por. Stelmach (2015): 96.

36 Wratny (2015): 200.

37 Wratny (2015): 200.

38 Wratny (2015): 201.
} 
rom recenzji na przedstawienie siebie jako specjalistów, a prezentowane w recenzjach oceny jako uzasadnione i wyważone. Podobny trend można dostrzec w drugim z analizowanych czasopism socjologicznych: „Przeglądzie Socjologicznym”. Z kolei w czasopismach z dziedziny zarządzania znacznie częściej pojawiają się pierwszy i trzeci z wyróżnionych tu typów recenzji. Recenzenci występują częściej w roli środowiskowych mentorów oraz pośredników między wiedzą naukową a praktyką zarządzania.

\section{WNIOSKI}

Przeprowadzona w artykule analiza kilkunastu recenzji zawartych w czasopismach z dziedziny nauk społecznych, socjologii i zarządzania pokazuje nie tylko różnice, lecz także i pewne trendy zmian. Czasopisma naukowe od początku służą nie tylko jako platforma prezentacji uprawianej przez naukowców nauki, lecz także miejsce sporów i polemik oraz budowania pozycji indywidualnych uczonych i ich szkół. Wraz z instytucjonalizacja nauki zastępowały jakże ważną od oświecenia po początek XX w. korespondencję prywatna, w której autorzy wyrażali nie tylko swoje zainteresowanie czy podziw dla autorów, ale nierzadko dezaprobatę dla wyrażanych poglądów. W odniesieniu do socjologii doskonale przedstawia to Wolf Lepenies ${ }^{39}$, wskazując nie tylko na proces zdobywania przez socjologię rangi nauki, ale także związek uprawiających ją osób z filozofami, historykami i pisarzami. Ich opinie, po latach czasami uważane za stronnicze lub chybione, są ważnym źródłem dla współczesnych badaczy. Obecnie, pod wpływem scharakteryzowanych na początku artykułu trendów, recenzje książek zmieniają nie tylko swoją formę, ale i funkcję. Zmianie też ulega sama rola recenzenta. Wpływ ekonomizacji życia społecznego i działań o charakterze marketingowym powoduje, że nierzadko recenzent realizuje wzór pochodzący z innych obszarów, dotąd obcych nauce. W odniesieniu do sztuki na zjawisko to zwraca uwagę Monika Małkowska, podkreślająca, że dzieła sztuki traktowane sa jako produkty, które trzeba „wypromować”. Sprzyja to osłabieniu świadomości potrzeby merytorycznej krytyki nieodzownej dla recepcji i oceny dzieł wprowadzanych w artystyczny obieg, które zastępowane są przez promocję dzieł i ich twórców ${ }^{40}$.

Drugi z kolei trend związany z biurokratyzacją nauki, którego jednym z elementów w Polsce jest nieprzyznawanie punktów za publikacje recenzji, może spowodować, że wymagajacca kompetencji, nakładu pracy i nierzadko otwartego sprzeciwu wobec przyjętych ocen i interpretacji działalność zostanie zastapiona omówieniami obfitującymi w silnie wartościujące określenia, promujacymi autorów, ich dzieła i wydawców. Na zjawisko to zwrócił uwagę Bogusław Śliwerski, którego jednak interesuje kwestia wpływu zarządzeń

\footnotetext{
${ }^{39}$ Por. Lepenies (1997).

40 Małkowska (2018).
} 
administracyjnych na motywacje naukowców do czytania książek i pisania recenzji w czasopismach, a nie wpływ takich rozwiąań na funkcjonowanie środowisk naukowych i zmiany roli, jaką w życiu naukowym odgrywa przegląd piśmiennictwa w czasopismach naukowych ${ }^{41}$.

\section{Piotr Górski}

Akademia Górniczo-Hutnicza w Krakowie

pgorski@zarz.agh.edu.pl

https://orcid.org/0000-0003-4018-2147

Andreski, S. (2002). Czarnoksięstwo w naukach społecznych. Warszawa: Oficyna Naukowa.

Barabasz, A. (2015). Elżbieta Kowalczyk [2014], Człowiek - organizacja - kariera. Siła psychologii stosowanej. Zarządzanie Zasobami Ludzkimi 1: 165-168.

Lepenies, W. (1997). Trzy kultury: Socjologia między literaturą a nauką. Poznań: Wydawnictwo Poznańskie.

Lewicka, D. (2018). Marta Juchnowicz (red. naukowa) [2016], Elastyczne zarządzanie kapitałem ludzkim z perspektywy interesariuszy. Zarządzanie Zasobami Ludzkimi 2: 105-108.

Małkowska, M. (2018). Niech sczezną krytycy! <http://kwartalnikwyspa.pl/monika-malkowska-niech-sczezna-krytycy/> [dostęp: 9.06. 2018].

Mucha, J. (2015). Marta Bucholc i socjologia Eliasa w Polsce. Kultura i Społeczeństwo 59(1): 197-200.

Rakusa-Suszczewski, M. (2017). Kerstin Lacobsson, Elżbieta Korolczuk (eds.), Civil Society Revisited. Lessons from Poland. Przegląd Socjologiczny 61(3): 142-148.

Romanowska, M. (2015). Praktyczny wymiar nauk o zarządzaniu. Jan Lichtarski. Organizacja i Kierowanie 4(169): 205-208.

Sadłoń, W. (2015). Moralność w kontekście społecznym. Janusz Mariański. Przegląd Socjologiczny 59(3): 181-184.

Stelmach, W. (2015). Wiesław Harasim, Jacek Dziewulski [2015], Zarządzanie twórcze. Zarządzanie Zasobami Ludzkimi 2: 93-96.

Śliwerski, B. (2017). Czy ma sens pisanie i publikowanie recenzji rozpraw naukowych w czasopismach? <http://sliwerski-pedagog.blogspot.com/2017/05/czy-ma-sens-pisanie-i-publikowanie. html> [dostęp: 9.06. 2018].

Tarkowska, E. (2015). Socjologia Muzyki. Kultura i Społeczeństwo 59(1): 200-202.

Woroniecka, G. (2015). Recenzje naukowe jako materiał badawczy. Przegląd Socjologiczny 64(4): $9-25$.

Woźniak, J. (2015). Mario Herger [2014], Gamification in Human Resources. Zarządzanie Zasobami Ludzkimi 2: 157-161.

Wratny, J. (2015). Grzegorz Wanio [2015], Derekrutacja czyli jak skutecznie rozwiązać stosunek pracy. Zarządzanie Zasobami Ludzkimi 3: 200-203.

\section{BOOK REVIEWS IN SOCIAL SCIENCE JOURNALS THEIR ROLE AND THREATS TO THEM}

\section{Sum mary}

The article concerns the functions of book reviews in scientific journals and the threats facing them. The first part of the article is an attempt to identify the functions of reviews in the dissemination of knowledge, ideas and scientific concepts, and in building the authority of authors of peer-reviewed books and their reviewers. The author presents the threats resulting from the

\footnotetext{
${ }^{41}$ Śliwerski (2017).
} 
monetization of social life and bureaucratization of science. In the second part of the article, based on empirical research, three types of reviews are presented: a review of a book by an outstanding author, of a book raising an important and interesting problem, and a review of a book addressed to practitioners. The article concludes by identifying the impact of changes in science and its environment on the role of the reviewer.

Keywords: social science; scientific journals; scientific book review 